\title{
PERANCANGAN DIGITAL DASHBOARD SYSTEM UNTUK MENYAJIKAN SENSITIVITY ANALYSIS KINERJA KEUANGAN PERUSAHAAN STUDI KASUS: PT XYZ
}

\author{
William Suhaidir dan Dana Indra Sensuse
}

Fakultas Ilmu Komputer, Universitas Indonesia, Kampus Baru UI Depok, Jawa Barat, 16424, Indonesia

E-mail: dana@cs.ui.ac.id

\begin{abstract}
Abstrak
Penelitian ini membahas tentang perancangan Digital Dashboard System pada PT XYZ dan dampaknya pada perusahaan tersebut dalam hal pengambilan keputusan. Digital Dashboard dirancang untuk dapat menyajikan sensitivity analysis kinerja keuangan rugi-labarugi-laba PT XYZ. Pada penelitian ini, proses perancangan Digital Dashboard dimulai dari identifikasi variabel, identifikasi user requirement, perancangan user interface hingga proses pengujian. Hasil penelitian ini menunjukan bahwa Digital Dashboard yang baik harus dapat merepresentasikan data yang padat dengan tampilan yang efisien, menarik dan mudah untuk dimengerti. Penelitian ini juga menyatakan bahwa Digital Dashboard yang baik dapat meningkatkan efektifitas eksekutif perusahaan dalam proses pengambilan keputusan.
\end{abstract}

Kata Kunci: digital dashboard system, sensitivity analysis

\begin{abstract}
This study discusses the design of the Digital Dashboard System on PT XYZ and its impact on the company in terms of decision making. Digital Dashboard is designed to provide sensitivity analysis of financial performance of PT XYZ's income statement. In this study, the Digital Dashboard design process starts from the identification of variables, identification of user requirements, designing the user interface to the testing process. The results of this study indicate that the good Digital Dashboard should be able to represent the solid data with the efficient view, attractive and easy to understand. The study also states that the good Digital Dashboard can improve the effectiveness of corporate executives in decision-making process.
\end{abstract}

Keywords: digital dashboard system, sensitivity analysis

\section{Pendahuluan}

Kinerja keuangan suatu perusahaan adalah hal yang penting bagi semua perusahaan. Hal ini harus selalu diukur dan dievaluasi untuk mendapatkan hasil yang paling maksimal. Salah satu kinerja keuangan yang penting adalah mengenai profit and loss atau biasa disebut dengan rugi-laba. Informasi yang akurat mengenai kinerja keuangan terutama pada bidang rugi-laba ini akan membantu para pemimpin perusahaan dalam mengambil keputusan yang paling tepat untuk perusahaannya.

Manajemen perusahaan perlu mengetahui faktor-faktor utama apa saja yang memengaruhi kinerja keuangan terutama pada bidang rugi-laba perusahaan. Selain itu pihak manajemen perusahaan juga berkepentingan untuk memahami pengaruh dari tiap faktor-faktor tersebut terhadap kinerja keuangan perusahaan.

Sensitivity analysis adalah sebuah teknik yang digunakan untuk menentukan bagaimana nilai yang berbeda-beda dari suatu variabel bebas berpengaruh pada suatu variabel tidak bebas. Teknik ini digunakan di dalam batasan-batasan tertentu yang tergantung dari satu atau lebih variabel yang dimasukkan. Sensitivity analysis juga merupakan salah satu cara untuk memperkirakan hasil dari suatu keputusan yang diambil oleh karena itu teknik ini dapat digunakan untuk mengetahui dan memahami faktor-faktor yang mempengaruhi kinerja keuangan perusahaan dan seberapa besar pengaruh dari faktor-faktor tersebut secara kuantitatif.

Saat ini terdapat suatu teknologi yang disebut dengan Digital Dashboard yang dapat digunakan untuk membantu menampilkan atau memodelkan suatu hasil analisis dalam bentuk laporan grafis yang interaktif. Digital Dashboard menyediakan akses yang sangat mudah terhadap data-data perusahaan dan dapat membantu mengawasi kinerja perusahaan serta mengoptimalkan akurasi pengambilan keputusan. Digital Dashboard yang baik dapat 
menggabungkan data-data yang ada kedalam suatu tampilan visual yang mudah dimengerti sehingga dengan para manajer dan pelaku bisnis dapat dengan mudah mengetahui kondisi dan kinerja perusahaan yang sedang mereka jalankan.

Pertanyaan penelitian ini adalah bagaimana bentuk rancangan suatu Digital Dashboard System untuk menyajikan hasil analisis sensitivity analysis yang sesuai dengan kebutuhan user. Selain itu, penelitian ini menjawab faktor-faktor apa saja yang menjadi parameter dalam kinerja keuangan perusahaan. Untuk hal ini, sebuah perusahaan yang dipilih sebagai studi kasus adalah PT XYZ. Perancangan Digital Dashboard System mengenai masalah rugi-laba perusahaan dibangun dalam penelitian ini. Sistem yang dirancang diharapkan dapat membantu manajer perusahaan dalam proses pengambilan keputusan di perusahaan tersebut.

Profil perusahaan, PT XYZ sudah berdiri lebih dari empat dekade. Perusahaan ini didirikan pada tahun 1968 dan merupakan perusahaan milik negara atau BUMN yang memiliki tipe perseroan terbatas. PT XYZ terintegrasi secara vertikal untuk melakukan semua tahap proses penambangan dimulai dari tahap eksplorasi, penambangan, peleburan, pemurnian sampai pada tahap pemasaran. Produk-produk utama dari PT XYZ antara lain feronikel, bijih nikel, emas, perak, dan bauksit.

PT XYZ merupakan perusahaan perseroan terbatas yang 35\% dari sahamnya dimiliki oleh publik. Mayoritas pemegang saham PT XYZ merupakan institusi asing. PT XYZ sudah terdaftar dalam bursa saham Indonesia dan Australia dan merupakan salah satu dari sedikit perusahaan di Indonesia yang terdaftar dalam bursa saham di luar negeri. Oleh karena hal ini maka PT XYZ sudah memenuhi standar kepemimpinan dan transparansi. Pemerintah memiliki saham PT XYZ sebesar $65 \%$ dan PT XYZ tidak dijalankan oleh birokrat. Tujuan utama PT XYZ adalah menciptakan nilai pemegang saham bukan untuk mengikuti petunjuk negara. Langkah yang PT XYZ ambil untuk meningkatkan nilai pemegang saham adalah dengan menurunkan biaya produksi dan melakukan operasi-operasi yang menguntungkan secara berkesinambungan.

PT XYZ menawarkan kesempatan yang sangat layak untuk para investor dan para rekan bisnis. PT XYZ memiliki karyawan yang kuat, fokus, manajemen yang baik, dan ahli pada bidangnya. Selain itu PT XYZ juga memiliki pelanggan jangka panjang yang setia dan performa perusahaan yang terus meningkat sementara terus menjalankan standar internasional dalam manajemen lingkungan dan pengembangan masyarakat.

Executive Information System (EIS). "Executive Information System (EIS) adalah sistem yang menyediakan informasi bagi eksekutif terutama informasi menyeluruh tentang kinerja organisasi untuk mendukung kegiatan dan pekerjaannya." (Faisal, 2009). Menurut Richardo (2008) EIS memanfaatkan teknologi komputer terbaru dalam bentuk database, hardware, dan aplikasi, untuk menempatkan data dalam format yang baik serta memiliki tujuan untuk menyediakan akses ke informasi yang lebih cepat dan mudah. Data yang diinterpretasikan oleh EIS bisa terdiri dari berbagai sumber baik eksternal maupun internal perusahaan (gambar 1). Pada intinya yang menjadi fokus dari EIS adalah data yang dapat diperoleh dengan cepat dan mudah sehingga membantu pihak eksekutif dalam melakukan pengambilan keputusan dan melihat peluang-peluang yang ada.

Pada tahun 1961, D. Donald Daniel dari McKinsey and Company, salah satu perusahaan konsultan terbesar di negaranya, mengenalkan istilah Critical Success Factor (CSF). Dia mengatakan bahwa hanya ada beberapa aktivitas pokok pada setiap perusahaan yang menentukan keberhasilan mereka. Aktivitas-aktivitas tersebut berbeda di setiap perusahaan dan dia menyebut aktivitas tersebut sebagai CSF. Suatu EIS yang baik dapat membantu pihak eksekutif perusahaan dalam melakukan pengawasan terhadap CSF yang mereka miliki. Oleh karena itu dalam perancangan suatu EIS di suatu perusahaan harus memperhatikan CSF yang dimiliki oleh perusahaan tersebut.

Karakteristik utama dari EIS adalah (Faisal, 2009) membantu pihak eksekutif dalam menemukan masalah ataupun mengenali suatu peluang, memiliki tingkat fleksibilitas yang tinggi dalam pembuatan laporan, memiliki kemampuan untuk melakukan analisis data ataupun informasi, misalnya trend analysis atau drill-down, memiliki kemudahan dalam pengoperasian, pada umumnya dilengkapi dengan perangkat komunikasi seperti email dan konferensi, menyediakan akses yang relatif mudah dan cepat ke sumber data, dan memiliki kemampuan untuk melakukan peringkasan, pemilihan, ataupun untuk melakukan perincian lebih lanjut.

Decision Support System (DSS) adalah sistem yang interaktif yang membantu pengambilan keputusan melalui penggunaan data dan model keputusan untuk memecahkan masalah yang sifatnya semiterstruktur dan tidak terstruktur (Mann \& Watson, 1984). Decision Support System dapat juga dikatakan sebagai suatu sistem yang dapat membantu manajer dalam memecahkan 
masalah semiterstruktur yang spesifik dengan cara memberikan usulan yang menuju kepada keputusan tertentu.

Menurut Simon (1997) ada empat tahapan Decision Support System atau tahapan dalam pengambilan keputusan. Tahapan pertama, kegiatan intelijen meliputi pemaparan masalah, pengumpulan data dan informasi, serta mengamati lingkungan untuk mencari kondisi-kondisi yang perlu diubah. Tahapan kedua, kegiatan merancang meliputi menemukan, mengembangkan, dan menganalisis berbagai alternatif tindakan yang mungkin untuk dilakukan. Tahapan ketiga yaitu kegiatan memilih dengan memilih satu kumpulan tindakan tertentu dari beberapa yang sudah ada. Tahapan keempat adalah kegiatan menelaah, yaitu dengan melakukan penilaian dari beberapa pilihan-pilihan sebelumnya yang pernah terjadi.

Masalah yang ada juga dibedakan menjadi tiga antara lain masalah terstruktur, tak terstruktur, dan semiterstruktur (Gorry \& Morton, 1971). Masalah terstruktur, merupakan suatu masalah yang memiliki struktur masalah pada tiga tahap pertama, yaitu intelijen, rancangan, dan pilihan. Masalah tak terstruktur, merupakan masalah yang sama sekali tidak memiliki struktur pada tiga tahap pertama. Masalah semi terstruktur, merupakan masalah yang memiliki struktur hanya pada satu atau dua tahap saja.

Tujuan dari Decision Support System ini antara lain (Indayanti, n.d.): (1) Membantu menyelesaikan masalah dengan tipe semiterstruktur. (2) Mendukung manajer dalam proses pengambilan keputusan. (3) Meningkatkan efektifitas pengambilan keputusan tetapi tidak meningkatkan efisiensi.

Tujuan-tujuan tersebut mengacu pada tiga prinsip dasar dari Decision Support System, yaitu: (1) Struktur masalah, masalah terstruktur dapat diselesaikan dengan menggunakan rumus-rumus yang sesuai, sedangkan untuk masalah tak terstruktur tidak dapat diselesaikan menggunakan komputer. DSS biasanya dikembangkan khususnya untuk menyelesaikan masalah yang semiterstruktur. (2) Dukungan keputusan, komputer berada di bagian terstruktur, sementara manajer berada di bagian tak terstruktur untuk memberi penilaian dan melakukan analisis. Hal ini mengakibatkan DSS yang dirancang tidak dapat menggantikan fungsi seorang manajer. Komputer dan manajer harus bekerja sama sebagai sebuah tim pemecahan masalah semiterstruktur. (3) Efektifitas keputusan, tujuan utama dari DSS bukan mempersingkat waktu pengambilan keputusan, tapi agar keputusan yang dihasilkan dapat lebih baik. Oleh karena itu DSS lebih terfokus pada peningkatan efektivitas.

Sensitivity analysis adalah studi tentang bagaimana menentukan seberapa besar sensitivitas suatu model untuk mengubah nilai parameter dan struktur dari model tersebut (Breierova \& Choudhari, 2001).

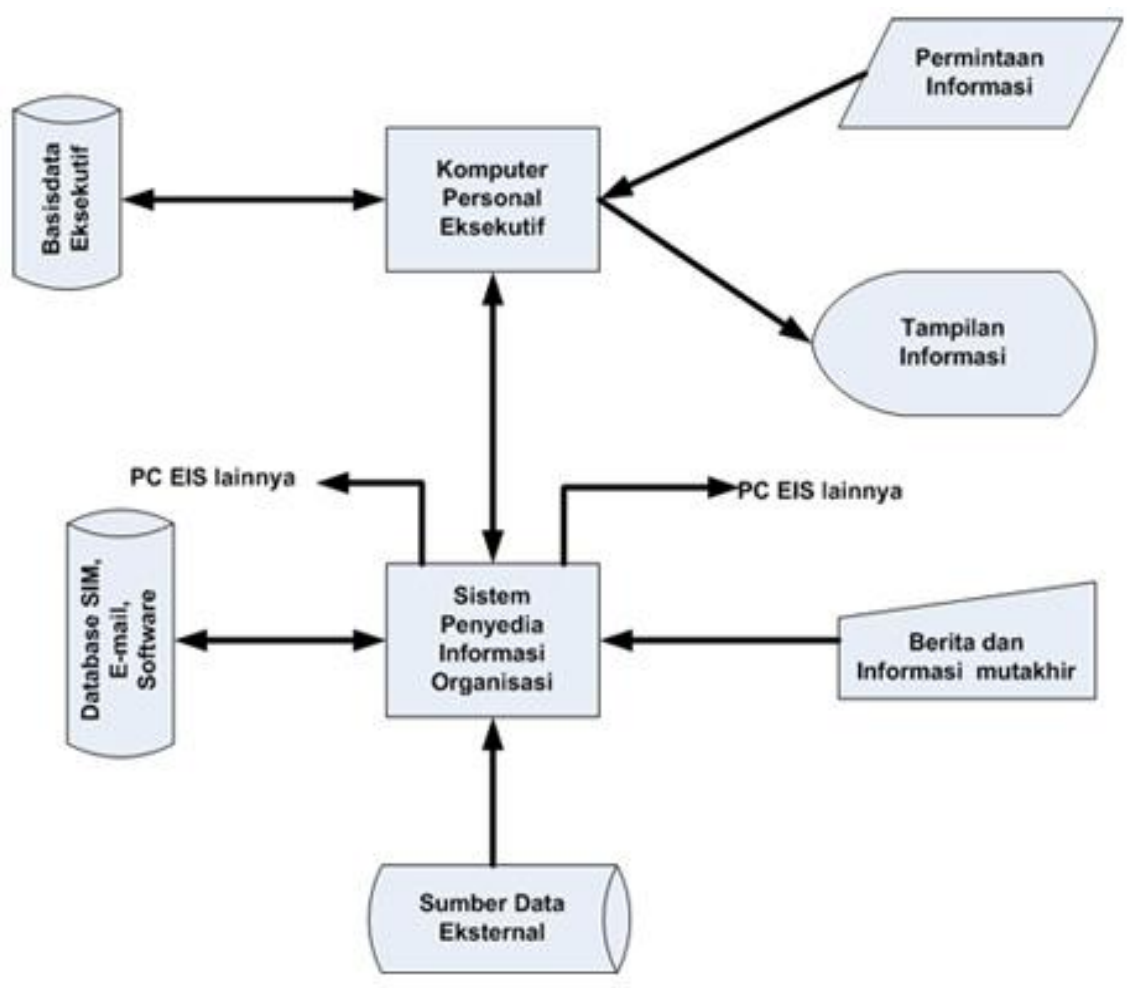

Gambar 1. Model Executive Information System (Faisal, 2009). 
Sensitivity analysis merupakan hal yang sangat penting untuk mendukung suatu sistem dalam pengambilan keputusan. Hal ini dikarenakan sensitivity analysis memungkinkan fleksibilitas dan adaptasi pada perubahan kondisi dan kepada kebutuhan situasi pengambilan keputusan yang berbeda. Sensitivity analysis menguji hubungan-hubungan seperti (Turban, Aronson, Ting-Peng Liang \& Sharda, 2007): (1) Akibat dari perubahan eksternal variabel atau variabel yang tidak dapat dikontrol dan parameter dari variabel hasil. (2) Akibat dari perubahan variabel keputusan terhadap variabel hasil. (3) Akibat dari ketidakpastian dalam memperkirakan variabel eksternal. (4) Akibat dari perbedaan interaksi yang berhubungan antara variabel.

Berikut diberikan beberapa kegunaan dari teknik sensitivity analysis, antara lain: (1) menambahkan detail mengenai variabel yang sensitif atau skenario, (2) mendapatkan prediksi yang lebih baik dari variabel eksternal yang sensitif, (3) menyimulasikan sistem dunia nyata untuk mengurangi sensitivitas sebenarnya, dan (4) peninjauan kembali model untuk mengeliminasi sensitivitas yang terlalu besar.

Turban, et al. (2007) mengatakan ada dua jenis sensitivity analysis yaitu Automatic Sensitivity Analysis dan Trial and Error Sensitivity Analysis. Automatic Sensitivity Analysis dilakukan pada model kuantitatif pengimplementasian standar seperti pada linear programming. Sensitivity analysis jenis ini dapat memberikan perbedaan di dalam variabel yang bervariasi tanpa memberikan akibat yang signifikan kepada solusi yang ditawarkan. Biasanya perubahan yang diperbolehkan dibatasi hanya satu saja dan juga harus variabel tertentu. Trial and Error Sensitivity Analysis menentukan akibat dari perubahan satu atau beberapa variabel dengan menggunakan pendekatan trial and error. Peneliti mengubah data masukan dan melakukan pemecahan pada masalah yang terjadi. Hal ini dilakukan terus berulang-ulang hingga solusi yang terbaik ditemukan.

Teknik sensitivity analysis dapat digunakan untuk melihat pengaruh antar variabel dalam konteks bisnis. Hal ini dapat membantu dalam mencari titik optimal dalam suatu bisnis sehingga keuntungan yang dicapai dapat mencapai titik maksimal dengan biaya yang minimal. Tetapi masih banyak hambatan-hambatan yang masih sering terjadi dalam penerapan sensitivity analysis dalam bisnis seperti banyaknya variabel interdependen yang tidak dapat dianalisis dan subjektivitas yang terjadi dalam menentukan titik maksimum dan minimum.

Di atas telah banyak disebutkan teori-teori yang menjadi dasar dari pembuatan suatu sistem untuk membantu para eksekutif perusahaan dalam proses pengambilan keputusan. Sistem tersebut tentunya tidak dapat dilepaskan dari proses interaksi yang terjadi antara manusia dan komputer. Sistem yang baik dapat menciptakan hubungan timbal balik yang positif antara manusia dan komputer sehingga tingkat fungsionalitas sistem semakin tinggi. Di bawah ini akan diberikan teori yang relevan dengan pengembangan Digital Dashboard System agar menjadi sistem yang memiliki interaksi yang positif. Teori tersebut mencakup Human Computer Interaction dan mengenai Digital Dashboard itu sendiri.

Human Computer Interaction menurut Dix, et al. (2003) bidang ilmu Human Computer Interaction atau HCI adalah ilmu yang mempelajari tentang bagaimana mendesain, mengevaluasi, dan mengimplementasikan sistem komputer yang interaktif sehingga dapat digunakan oleh manusia dengan mudah. Interaksi menjadi maksimal apabila kedua belah pihak mampu memberikan stimulan dan respon yang saling mendukung. Jika salah satu tidak bisa, maka interaksi akan mengalami hambatan atau bahkan menuju pembiasan tujuan. Jadi definisi dari interaksi antara komputer dan manusia adalah sebuah hubungan antara manusia dan komputer yang mempunyai karakteristik tertentu untuk mencapai suatu tujuan tertentu dengan menjalankan sebuah sistem yang bertopengkan sebuah antarmuka.

Berikut ini beberapa hal yang menjadi prinsip utama dalam mendesain sistem antarmuka yang baik dengan memerhatikan karakteristik manusia dan komputer (Dix, et al., 2003): User compatibility, Product compatibility, Task compatibility, Work flow compatibility, Consistency, Familiarity, Simplicity, Direct manipulation, Control, What You See Is What You Get, Flexibility, Responsiveness, Invisible Technology, Robustness, Protection, Ease of learning and ease of use.

Evaluasi pada sistem interaksi manusia dan komputer atau HCI mempunyai arti luas salah satunya adalah suatu teknik atau metode yang berperan melihat apakah hasil rancangan yang telah dilaksanakan sudah melalui proses uji coba sistem, ataupun rancangan tersebut telah dibuat sesuai dengan keinginan dan kebutuhan dari pemakai. Proses evaluasi ini memiliki beberapa determinan yang harus diperhatikan (Shneiderman, 1992): (1) Tahap perancangan (awal, tengah, atau akhir). (2) Perkiraan jumlah user. (3) Biaya yang diperlukan untuk melakukan pengujian. (4) Pengalaman dari tim perancang dan tim penguji. (5) Tingkat kekritisan sistem 
antarmuka. (6) Waktu yang dibutuhkan untuk pengujian.

Digital Dashboard menurut Beuschel (2006) aplikasi Digital Dashboard System sudah mulai dipakai di beberapa perusahaan beberapa tahun ini dan akan semakin berkembang lagi baik dari segi kuantitas maupun kualitas. Faktanya sekarang ini adalah hampir setiap perusahaan dilengkapi oleh sistem informasi yang sangat besar, infrastruktur mereka sudah sangat tergantung oleh software yang membantu mereka mengolah data yang sangat besar.

Awalnya, representasi data dan user interface sistem administrasi dan operasional tidak dirancang untuk digunakan di tingkat manajemen. Oleh karena itu dibutuhkan jembatan untuk menghubungkan keduanya. Banyak perusahaan yang merasakan perlunya merancang suatu sistem tampilan yang dapat membantu keperluan manajemen perusahaan. Ide dari Digital Dashboard ini adalah untuk membantu menampilkan kumpulan data dalam suatu tampilan yang padat dan ringkas. Hal ini akan memberikan gambaran singkat kepada para manajer mengenai keadaan perusahaan sehingga membantu mereka dalam hal pengambilan keputusan. Digital Dashboard tidak hanya berperan untuk menampilkan data-data dalam tampilan yang padat dan tepat, tetapi juga dalam membuat data-data ini menjadi lebih mudah dibaca yang menyebabkan keputusan dapat diambil dengan cepat dan mudah. Jadi, dapat dikatakan bahwa Digital Dashboard berfungsi sebagai sistem perantara antara infrastruktur teknologi dan kebutuhan akan informasi di tingkat pengambilan keputusan.

Ada tiga karakteristik dari Digital Dashboard yang penting antara lain (Beuschel, 2006). Pertama adalah visualisasi. Semua jenis tampilan visual seperti grafik batang, grafik lingkaran, alat pengukur, dan lain-lainnya dapat digunakan selama manajer dapat membacanya dan mengerti dengan baik. Contoh yang paling umum adalah lampu rambu-rambu lalu lintas di mana merah, kuning, dan hijau melambangkan suatu keadaan. Hal ini dapat peneliti terapkan pada Digital Dashboard perusahaan di mana hal tersebut melambangkan jumlah produksi. Tujuan utamanya adalah untuk menandakan keadaan yang positif ataupun negatif yang diturunkan dari data yang ada. Tanda yang mudah dimengerti ini memberikan reaksi yang lebih cepat dari para manajer untuk mengambil sebuah keputusan.

Kedua, pemilihan data yang relevan. Sistem informasi untuk manajemen mendapatkan hasilnya dari data yang sangat banyak yang didapat dari berbagai sumber di dalam suatu perusahaan. Oleh karena itu, suatu sistem harus menyediakan data yang sesuai mengenai kondisi perusahaan saat ini dari berbagai unit. Sebuah Digital Dashboard secara umum juga memiliki tujuan yang sama dengan memadatkan informasi yang kompleks menjadi representasi yang lebih sederhana. Semua perincian tidak perlu ditampilkan, tetapi hanya informasi yang sudah dipadatkan saja yang perlu ditampilkan. Hal ini sudah cukup memberikan gambaran mengenai keadaan perusahaan secara umum. Dari sudut pandang ini peneliti dapat melihat bahwa Digital Dashboard bukanlah merupakan suatu sistem yang berdiri sendiri tetapi merupakan tampilan terdepan untuk semua sistem-sistem kompleks lainnya di organisasi.

Ketiga, pengawasan dan interaksi. Sebuah Digital Dashboard dapat menampilkan kumpulan data yang sangat besar yang berasal dari berbagai macam sistem software maupun hardware dalam tampilan yang padat. Rincian yang ditampilkan dan bentuk tampilan tergantung dari tujuan bisnis yang diinginkan. Proses reduksi dari data yang sangat besar menjadi tampilan yang sangat padat dilakukan oleh suatu algoritma. Hal ini membutuhkan proses kuantifikasi dan kualifikasi data yang ada selama masa pengembangan sistem. Ini merupakan proses pemilihan yang sangat sensitif dan sangat tergantung pada end user. Perusahaan harus melakukan pengawasan terhadap kinerja perusahaan untuk memeroleh data-data yang tepat. Beberapa jenis dari Digital Dashboard juga membutuhkan interaksi dengan real-time database untuk memberikan peringatan dan informasi yang akurat tepat pada waktunya.

Kerangka Pikir Penelitian, dalam penelitian ini dilakukan tiga hal, yaitu: identifikasi parameter yang sesuai, identifikasi user requirement yang tepat, dan merancang desain user interface yang baik. Ketiga hal ini merupakan dasar dari pembuatan dari Digital Dashboard System yang baik dan diharapkan dapat membantu eksekutif perusahaan dalam proses pengambilan keputusan. Setelah ketiga hal tersebut dilakukan maka dihasilkan sebuah Digital Dashboard. Perancangan Digital Dashboard ini juga didasarkan pada teori-teori yang terdapat pada ilmu Human Computer Interaction dengan tujuan terjadinya suatu interaksi yang positif antara user dengan aplikasi. Selanjutnya aplikasi ini akan melalui proses uji coba. Proses uji coba ini dilakukan untuk mengetahui dan menjawab salah satu pertanyaan dari penelitian ini yaitu apakah Digital Dashboard dapat membantu eksekutif perusahaan dalam proses pengambilan keputusan. 


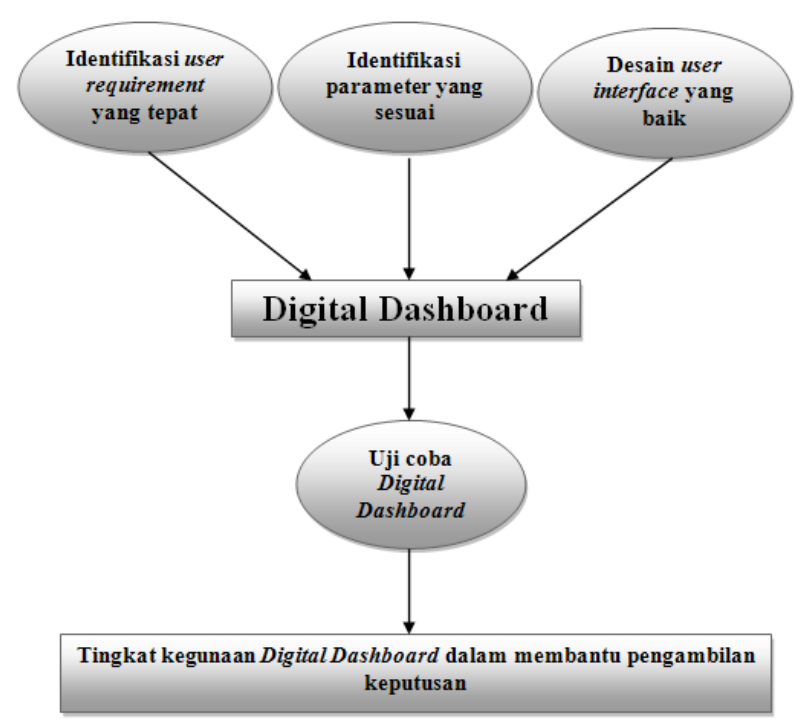

Gambar 2. Bagan kerangka pikir penelitian.

\section{Metodologi}

Terdapat beberapa tahap dalam penelitian yang dilakukan yaitu tahap awal, penentuan parameter, pengembangan aplikasi, dan pengujian (gambar 2). Tahap awal adalah suatu tahap pengumpulan data dan informasi yang dibutuhkan untuk melakukan penelitian. Tahap ini terdiri dari tiga langkah.

Pertama, studi literatur. Studi literatur adalah tahap penyiapan konsep yang jelas mengenai penelitian yang akan dilakukan. Pada tahap ini, diperoleh pemahaman yang jelas mengenai halhal penting yang menjadi dasar ilmu dari penelitian ini. Studi literatur ini dilakukan dengan cara membaca beberapa buku, jurnal dan beberapa artikel yang didapat dari internet. Beberapa konsep yang dipelajari diantaranya Executive Information Management, Decision Support System, Sensitivity Analysis, Human Computer Interaction, dan Digital Dashboard.

Kedua, perumusan masalah. Setelah melakukan studi literatur dan memeroleh pemahaman yang baik mengenai konsep-konsep penting yang terkait, maka tahap berikutnya adalah perumusan masalah. Tahap ini memberikan tujuan dan sasaran dari penelitian ini. Hasil dari tahap ini adalah pertanyaan-pertanyaan yang akan dijawab oleh hasil dari penelitian ini.

Ketiga, penentuan studi kasus. Setelah diperoleh rumusan masalah yang harus diselesaikan maka tempat untuk melakukan studi kasus ditentukan. PT XYZ dipilih sebagai tempat untuk melakukan studi kasus. PT XYZ adalah suatu perusahaan yang bergerak di bidang pertambangan. Perusahaan ini membutuhkan suatu sistem yang dapat mendukung proses pengambilan keputusan perusahaan. Sistem tersebut harus dapat menyajikan sensitivity analysis mengenai kinerja keuangan perusahaan. Untuk hal ini PT XYZ meminta PT EMS Paramitra yang merupakan sebuah perusahaan IT Consultant untuk mengembangkan sistem tersebut.

Berikutnya adalah tahap penentuan parameter. Tahap ini adalah tahap di mana didapatkan parameter-parameter apa saja yang berpengaruh pada kinerja keuangan perusahaan. Tahap ini terdiri dari dua langkah. Pertama, wawancara. Pada tahap ini, wawancara kepada pihak manajemen PT XYZ dilakukan. Wawancara akan dilakukan dengan cara lisan. Tujuan dari tahap ini adalah untuk memeroleh data dan informasi yang jelas mengenai proses bisnis perusahaan. Hal ini akan membantu untuk dapat lanjut ke tahap berikutnya yaitu menentukan parameter. Kedua, penentuan parameter. Parameter yang dimaksud disini adalah faktorfaktor apa saja yang mempengaruhi kinerja keuangan PT XYZ. Penentuan parameter ini akan lebih difokuskan pada faktor-faktor yang mempengaruhi kinerja keuangan dibidang profit and loss. Data dan informasi yang didapat dari hasil wawancara dengan pihak manajemen perusahaan akan sangat membantu dan menjadi dasar penentuan parameter-parameter ini. Selain mengidentifikasi parameter-parameter tersebut, hubungan diantara masing-masing parameter harus dicari.

Setelah parameter ditentukan, tahap berikutnya adalah tahap pengembangan aplikasi. Pada tahap ini, pengembangan aplikasi Digital Dashboard dilakukan. Pengembangan aplikasi ini akan dilakukan di PT EMS Paramitra. Tujuan dari 
pengembangan aplikasi ini adalah agar dapat diketahui bagaimana merancang user interface untuk suatu Digital Dashboard yang efektif dan hanya menampilkan informasi yang relevan saja. Selain itu, ingin diketahui apakah aplikasi Digital Dashboard ini dapat membantu seorang eksekutif perusahaan dalam hal pengambilan keputusan. Aplikasi Digital Dashboard ini akan dikembangkan dengan menggunakan tools untuk membuat Digital Dashboard yang bernama Crystal Xcelsius.

Tahap pengujian adalah tahap terakhir dari penelitian ini. Tahap ini bertujuan untuk melakukan pengujian terhadap Digital Dashboard System yang dikembangkan dan mendapat kesimpulan mengenai pengaruh atau kegunaan sistem tersebut untuk perusahaan. Tahap ini terdiri dari dua langkah.

Pertama, pengujian. Tahap pengujian adalah suatu tahap untuk melihat apakah aplikasi Digital Dashboard System dapat membantu dalam proses bisnis PT XYZ. Pengujian akan dilakukan oleh pihak manajemen dari PT XYZ. Suatu lembar penilaian kepada pihak manajemen diberikan untuk diisi. Hasil dari lembar penilaian tersebut akan memberikan informasi mengenai tingkat kegunaan Digital Dashboard tersebut untuk perusahaan dan tingkat kesesuaian user interface dengan kebutuhan dan keinginan perusahaan.

Kedua, pembuatan kesimpulan. Semua informasi dan data yang dilakukan selama penelitian dan pengembangan Digital Dashboard dikumpulkan. Dari hasil tersebut, analisis dan kesimpulan mengenai hasil dari penelitian ini dibuat. Kesimpulan ini menjawab pertanyaanpertanyaan yang menjadi rumusan masalah dalam penelitian ini.

\section{Analisis dan Pembahasan}

Kedudukan Digital Dashboard, penelitian ini menggunakan studi kasus di PT XYZ dan membuat Digital Dashboard System untuk perusahaan tersebut. Oleh karena itu, pemahaman secara garis besar mengenai keadaan sistem informasi di PT XYZ sangat penting. Dengan pemahaman ini, dapat diketahui posisi dan kegunaan Digital Dashboard yang akan dikembangkan sehingga rancangan yang dibuat dapat lebih sesuai dan efektif.

PT XYZ merupakan perusahaan tambang yang berskala besar. Hal ini menyebabkan arus data pada perusahaan ini sangatlah padat dan besar. Untuk dapat mencapai tingkat efisiensi dan efektivitas yang baik PT XYZ menggunakan Enterprise Resource Planning (ERP) dalam melakukan proses bisnisnya. ERP yang digunakan oleh PT XYZ dikembangkan oleh PT Mincom Australia dan bernama Ellipse.

Seperti yang diketahui bahwa terdapat dua jenis tipe perangkat lunak ERP saat ini yaitu Online Transaction Processing (OLTP) dan Online Analytical Processing (OLAP). Ellipse merupakan ERP yang hanya memiliki tipe OLTP yaitu hanya dapat menangani transaksi-transaksi data saja dan tidak dapat melakukan analisis data seperti yang dapat dilakukan ERP bertipe OLAP. Hal ini menyebabkan sistem informasi PT XYZ memiliki kekurangan dalam bidang analisis data.

Untuk mengatasi hal ini PT XYZ meminta PT EMS Paramitra untuk melakukan pengembangan sistem yang terhubung dengan ERP Ellipse dan dapat melakukan analisis data yang diberi nama Sensitivity Analysis Modelling.

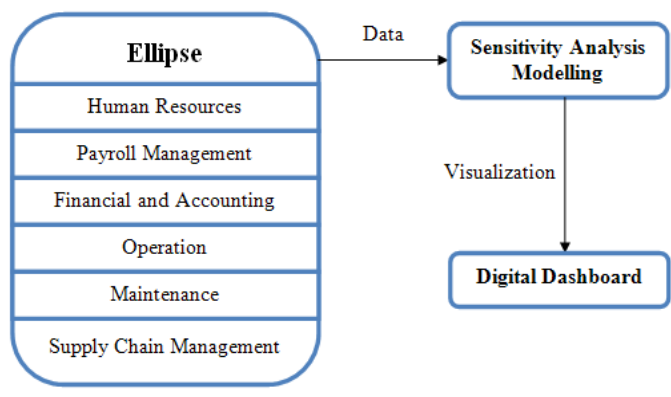

Gambar 3. Sistem informasi PT XYZ.

Gambar 3 di atas adalah bagan yang menggambarkan sistem informasi PT XYZ secara garis besar serta menjelaskan juga kedudukan Digital Dashboard yang akan dikembangkan. Terlihat pada bagan bahwa PT XYZ menggunakan Ellipse untuk melakukan fungsifungsi transaksi data atau yang disebut dengan OLTP. Ellipse sudah mencakup semua fungsi bisnis perusahaan PT XYZ seperti manajemen sumber daya manusia, gaji pegawai, operasional, Maintenance, Supply Chain Management, dan Financial and Accounting. Tetapi seperti yang telah dijelaskan sebelumnya bahwa Ellipse tidak memiliki fungsi analisis data oleh karena itu PT EMS Paramitra mengembangkan suatu sistem yang disebut dengan Sensitivity Analysis Modelling. Sistem ini akan menerima data-data dari Ellipse sebagai input dan akan melakukan proses pada data-data tersebut. Output dari proses tersebut adalah hasil analisis dari data-data yang diberikan yang memiliki tampilan yang rumit dan sulit dimengerti. Hal inilah yang menjadi alasan utama pembuatan Digital Dashboard. Hasil analisis yang banyak dan rumit akan diseleksi sehingga hanya beberapa komponen penting saja yang ditampilkan. Digital Dashboard akan membantu memvisualisasikan komponen- 
komponen penting tersebut ke dalam tampilan yang lebih mudah dibaca dan dapat digunakan langsung oleh pihak eksekutif perusahaan dalam pengambilan keputusan.

TABEL I

PARAMETER-PARAMETER YANG BERPENGARUH PADA RUGILABA PT XYZ

\begin{tabular}{|c|c|c|}
\hline \multicolumn{3}{|c|}{ Penghasilan (Revenue) } \\
\hline & Parameter dasar & $\begin{array}{c}\text { Parameter yang } \\
\text { mempengaruhi } \\
\text { parameter dasar }\end{array}$ \\
\hline $\begin{array}{l}\text { Jumlah } \\
\text { produksi yang } \\
\text { terjual }\end{array}$ & $\begin{array}{l}\text { Feronikel (Ton) } \\
\text { Nikel HG (Ton) } \\
\text { Nikel LGSO (Ton) } \\
\text { Emas (Kg) } \\
\text { Perak (Kg) } \\
\text { Bauksit (Ton) } \\
\end{array}$ & \\
\hline $\begin{array}{l}\text { Harga } \\
\text { penjualan } \\
\text { produk }\end{array}$ & $\begin{array}{l}\text { Feronikel } \\
\text { Nikel HG } \\
\text { Nikel LGSO } \\
\text { Emas } \\
\text { Perak } \\
\text { Bauksit } \\
\end{array}$ & $\begin{array}{l}\text { Nilai tukar } \\
\text { terhadap } \\
\text { Amerika (USD) }\end{array}$ \\
\hline $\begin{array}{l}\text { Pendapatan } \\
\text { lainnya }\end{array}$ & $\begin{array}{l}\text { Deposito dan jasa } \\
\text { giro } \\
\text { Selisih Kurs } \\
\text { Lain-lain } \\
\end{array}$ & \\
\hline & Biaya $($ Cost $)$ & \\
\hline & Parameter dasar & $\begin{array}{c}\text { Parameter yang } \\
\text { mempengaruhi } \\
\text { parameter dasar }\end{array}$ \\
\hline $\begin{array}{l}\text { Biaya } \\
\text { produksi }\end{array}$ & Beban bahan bakar & $\begin{array}{l}\text { Jumlah produksi dan } \\
\text { harga bahan bakar }\end{array}$ \\
\hline & $\begin{array}{l}\text { Beban bahan baku } \\
\text { Beban bahan } \\
\text { (Emas/Perak) } \\
\text { Beban jasa } \\
\text { Beban pegawai } \\
\text { Beban pajak dan } \\
\text { retribusi } \\
\text { Beban Amortisasi } \\
\text { Beban depresiasi } \\
\text { Iuran eksploitasi } \\
\text { Beban produksi } \\
\text { lainnya }\end{array}$ & $\begin{array}{l}\text { Bonus yang diberikan } \\
\text { Pemakaian bijih bes } \\
\text { (khusus nikel) }\end{array}$ \\
\hline Biaya usaha & $\begin{array}{l}\text { Beban administrasi } \\
\text { Beban pemasaran } \\
\text { Beban penelitian } \\
\text { dan pengembangan }\end{array}$ & \\
\hline
\end{tabular}

Identifikasi Parameter, rumus yang paling mendasar dari rugi-laba suatu perusahan adalah penghasilan perusahaan dikurangi dengan biaya yang dikeluarkan perusahaan. Jika penghasilan lebih besar dari biaya maka perusahaan akan memeroleh keuntungan tetapi jika biaya lebih besar dari penghasilan maka perusahaan akan mengalami kerugian. Oleh karena hal inilah maka parameter-parameter yang berpengaruh pada rugilaba perusahaan tentunya adalah hal-hal yang mempengaruhi biaya dan penghasilan perusahaan. Berikut diberikan seluruh parameter yang berpengaruh pada rugi-laba perusahaan.
Berikut diberikan rumus-rumus yang menunjukkan keterkaitan antara parameterparameter yang telah teridentifikasi pada tabel I secara umum. Rumus-rumus ini akan dipakai dalam proses penghitungan rugi-laba dalam perancangan Digital Dashboard.

Penghasilan (Revenue): Jumlah produksi yang terjual $\mathrm{x}$ Harga penjualan produk $\mathrm{x}$ Nilai tukar Rupiah terhadap Dollar Amerika (USD).

Biaya total (Total Cost): Biaya produksi + Biaya usaha. Rugi-laba (Profit \& Loss): Penghasilan (Revenue) - Biaya Total (Total cost) + Pendapatan lainnya.

Rumus-rumus di atas dapat dimodelkan secara matematis dengan menentukan objective function, decision variabels, constraint, dan parameter (konstanta).

Objective function:

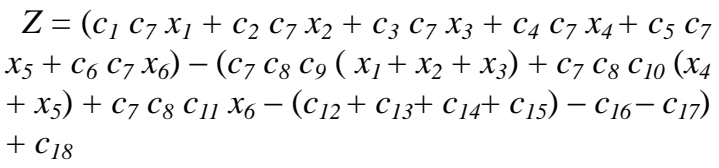

Di mana $Z=$ Keuntungan yang diterima oleh PT $\mathrm{XYZ}$ dalam Rupiah per tahun.

Decision variables

$x_{1}=$ Jumlah produksi feronikel dalam satuan ton per tahun

$x_{2}=$ Jumlah produksi nikel HG dalam satuan ton per tahun

$x_{3}=$ Jumlah produksi nikel LGSO dalam satuan ton per tahun

$x_{4}=$ Jumlah produksi emas dalam satuan ton per tahun

$x_{5}=$ Jumlah produksi perak dalam satuan ton per tahun

$x_{6}=$ Jumlah produksi bauksit dalam satuan ton per tahun

Parameter (konstanta)

$c_{1} \quad$ = Harga feronikel

$c_{2}=$ Harga nikel $\mathrm{HG}$

$c_{3}=$ Harga nikel LGSO

$c_{4}=$ Harga emas

$c_{5}=$ Harga perak

$c_{6}=$ Harga bauksit

$c_{7}=$ Exchange rate (Nilai tukar Rupiah terhadap USD)

$c_{8}=$ Harga bahan bakar

$c_{9}=$ Koefisien penggunaan bahan bakar untuk produksi nikel

$c_{10}=$ Koefisien penggunaan bahan bakar untuk produksi emas dan perak

$c_{11}=$ Koefisien penggunaan bahan bakar untuk produksi bauksit

$c_{12}=$ Beban bahan baku nikel

$c_{13}=$ Beban bahan baku emas

$c_{14}=$ Beban bahan baku perak 
$c_{15}=$ Beban bahan baku bauksit

$c_{16}=$ Beban produksi lainnya

$c_{17}=$ Beban biaya usaha

$c_{18}=$ Pendapatan lainnya

Constraint

$$
\begin{array}{ll}
x_{1} \leq 25.000 & x_{4} \leq 15 \\
x_{1} \geq 0 & x_{4} \geq 0 \\
x_{2} \leq 7.500 .000 & x_{5} \leq 30 \\
x_{2} \geq 0 & x_{5} \geq 0 \\
x_{3} \leq 5.000 .000 & x_{6} \leq 1.500 .000 \\
x_{3} \geq 0 & x_{6} \geq 0
\end{array}
$$

Setelah memasukkan nilai dari konstantakonstanta berdasarkan data yang ada maka peneliti akan memeroleh objective function berikut:

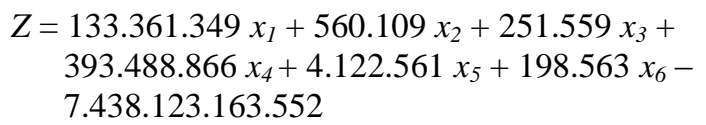

Dari objective function di atas dapat dilakukan pencarian titik maksimal yaitu keuntungan tertinggi yang dapat dicapai oleh perusahaan dalam 1 tahun. Hasil pencarian tersebut menghasilkan nilai-nilai berikut:

$x_{1}=25.000$

$x_{2}=7.500 .000$

$x_{3}=5.000 .000$

$x_{4}=15$

$x_{5}=30$

$x_{6}=1.500 .000$

$Z=9.096 .520 .000 .000$

Dari nilai tersebut dapat melihat bahwa PT XYZ dapat mencapai keuntungan maksimal sebesar 9,096,520,000,000 Rupiah apabila perusahaan tersebut memproduksi produk tambangnya sebesar nilai variabel di atas. Disini dapat dilihat bahwa masing-masing nilai dari tiap variabel adalah kapasitas maksimum produksi pabrik, hal ini menandakan bahwa beban produksi tiap produk lebih kecil daripada keuntungan yang akan didapat dari produksi produk tersebut. Pada tabel II (sensitivity analysis report) yang diberikan dapat dilihat bahwa setiap variabel memiliki shadow price lebih besar dari nol yang berarti setiap variabel tersebut merupakan variabel sensitif. Selain itu setiap variabel juga memiliki allowable increase tak terhingga yang berarti bahwa kapasitas produksi masing-masing pabrik dapat terus dinaikkan dan keuntungan akan semakin besar. Model matematika sederhana ini sebenarnya masih memiliki kekurangan karena tentunya hal ini tidak dapat diaplikasikan pada keadaan sebenarnya. Perusahaan tidak dapat memproduksi barang sebanyak-banyaknya karena tetap harus memperhatikan permintaan pasar yang cenderung tidak tetap. Tujuan dari model ini hanya untuk memberikan gambaran mengenai sensitivity analysis pada kinerja keuangan rugilaba PT XYZ. Digital Dashboard akan melakukan proses simulasi berdasar dari model ini.

Sebelumnya telah disebutkan parameterparameter yang berpengaruh pada rugi-laba perusahaan dan akan menjadi dasar penghitungan rugi-laba pada aplikasi Digital Dashboard yang akan dibuat. Tetapi hanya sebagian dari parameter tersebut yang akan ditampilkan pada Digital Dashboard sisanya hanya akan menjadi dasar penghitungan saja. Hal ini dikarenakan sifat dari Digital Dashboard yaitu ringkas, efisien, dan efektif. Dasar dari pemilihan parameter yang ditampilkan pada Digital Dashboard adalah: parameter tersebut harus memiliki pengaruh besar terhadap rugi-laba perusahaan, parameter tersebut mempengaruhi parameter-parameter lainnya, dan parameter tersebut sesuai dengan kebutuhan simulasi dari Digital Dashboard yang akan dikembangkan.

TABEL II

SENSITIVITY ANALYSIS REPORT RUGI-LABA PT XYZ

\begin{tabular}{lrrrcr}
\hline \hline Name & Final Value & Reduced Cost & $\begin{array}{c}\text { Objective } \\
\text { Coefficient }\end{array}$ & $\begin{array}{c}\text { Allowable } \\
\text { Increase }\end{array}$ & $\begin{array}{c}\text { Allowable } \\
\text { Decrease }\end{array}$ \\
\hline Feronikel & 25000.00 & 0.00 & 133361349 & $1 \mathrm{E}+30$ & 133361349 \\
Nikel HG & 7500000.00 & 0.00 & 560109 & $1 \mathrm{E}+30$ & 560109 \\
Nikel LGSO & 5000000.00 & 0.00 & 251559 & $1 \mathrm{E}+30$ & 251559 \\
Emas & 15.00 & 0.00 & 393488865.9 & $1 \mathrm{E}+30$ & 393488865.9 \\
Perak & 30.00 & 0.00 & 4122561.198 & $1 \mathrm{E}+30$ & 4122561.198 \\
Bauksit & 1500000.00 & 0.00 & 198563 & $1 \mathrm{E}+30$ & 198563 \\
Emas & 15.00 & 393488865.89 & 15 & $1 \mathrm{E}+30$ & 15 \\
Feronikel & 25000.00 & 133361349.00 & 25000 & $1 \mathrm{E}+30$ & 25000 \\
Perak & 30.0 & 4122561.20 & 30 & $1 \mathrm{E}+30$ & 30 \\
Nikel LGSO & 5000000.00 & 251559.00 & 5000000 & $1 \mathrm{E}+30$ & 5000000 \\
Bauksit & 1500000.00 & 198563.00 & 1500000 & $1 \mathrm{E}+30$ & 1500000 \\
Nikel HG & 7500000.00 & 560109.00 & 7500000 & $1 \mathrm{E}+30$ & 7500000 \\
\hline \hline
\end{tabular}


Terdapat beberapa parameter yang akan ditampikan pada Digital Dashboard untuk keperluan simulasi rugi-laba PT XYZ. Diantaranya adalah exchange rate, fuel, bonus karyawan, jumlah produksi dan harga produk, Use ore.

Exchange rate (nilai tukar) yang dimaksud disini adalah nilai tukar mata uang Rupiah terhadap mata uang Dollar Amerika (USD). Hal ini sangat berpengaruh terhadap rugi-laba perusahaan karena PT XYZ memeroleh penghasilannya dalam bentuk Dollar Amerika. Semakin tinggi nilai Dollar Amerika terhadap Rupiah semakin besar penghasilan yang PT XYZ dapatkan. Sebagai contoh jika PT XYZ mendapat penghasilan tahun 2010 sebesar USD 100,000 dan pada saat itu nilai tukar USD 1 sama dengan 10,000 Rupiah maka PT XYZ akan mendapatkan uang sebesar 1 milyar Rupiah, tetapi jika nilai tukar USD 1 sama dengan 12,000 Rupiah maka PT XYZ akan mendapatkan uang yang lebih besar yaitu 1,2 milyar Rupiah.

Fuel (bahan bakar), pengertian bahan bakar adalah harga Bahan Bakar Minyak (BBM) per barrel di Indonesia. Dalam melakukan proses bisnisnya baik proses produksi maupun distribusi PT XYZ melakukan konsumsi bahan bakar. Hal ini mutlak dibutuhkan baik untuk pengoperasian mesin-mesin pabrik maupun untuk pengoperasian alat transportasi untuk distribusi. Harga BBM yang tinggi akan membuat keuntungan yang diperoleh PT XYZ semakin kecil. Hal ini dikarenakan penghasilan yang didapat PT XYZ harus dikurangi biaya konsumsi bahan bakar yang besar sehingga mengurangi penghasilan bersih PT XYZ.

Bonus karyawan, jumlah bonus yang diberikan oleh PT XYZ terhadap para karyawannya ternyata juga termasuk parameter penting yang mempengaruhi jumlah keuntungan yang diterima oleh PT XYZ. Tentu saja semakin besar bonus yang diberikan pada karyawannya semakin kecil keuntungan yang diperoleh oleh PT XYZ.

Jumlah produksi dan harga produk, PT XYZ merupakan perusahaan pertambangan yang bentuk dari hasil produksinya adalah barang tambang. Perusahaan ini tidak hanya menghasilkan satu jenis barang tambang saja tetapi menghasilkan beberapa jenis barang tambang yang tentu saja memberikan tingkat keuntungan yang berbeda. PT XYZ memiliki beberapa barang tambang utama yang menjadi andalan dan berpengaruh secara signifikan terhadap rugi-laba perusahaan, diantaranya: nikel, emas, perak, bauksit. Hal penting yang harus diperhatikan adalah bagaimana mendapatkan keuntungan dari penjualan produk-produk tersebut. Hal ini sangat berkaitan erat dengan jumlah produksi dan harga yang ditetapkan atas produk tersebut. Harga jual yang ditetapkan harus dapat melebihi atau setidaknya menutup seluruh biaya produksi agar perusahaan tidak mengalami kerugian. Jumlah produksi juga berpengaruh karena semakin banyak jumlah yang diproduksi harga jual bisa ditekan atau yang dikenal dengan sebutan economy of scale.

Use ore (Nickel), seperti yang telah disebutkan sebelumnya bahwa PT XYZ melakukan produksi feronikel yang merupakan pencampuran antara besi dan nikel. Pada umumnya feronikel merupakan campuran dari $80 \%$ besi dan $20 \%$ nikel, tetapi PT XYZ dapat mengubah komposisi campuran ini sesuai kebutuhan. Semakin kecil campuran besi yang diberikan pada feronikel maka semakin sedikit biaya produksi yang harus dikeluarkan oleh PT XYZ. Jika feronikel yang mengandung campuran besi yang lebih sedikit itu dijual dengan harga yang sama tentu saja PT XYZ akan mendapatkan keuntungan yang lebih besar.

Rancangan Digital Dashboard, tahap pertama yang dilakukan adalah melakukan identifikasi user requirement. Pengertian user adalah pihak pengguna yaitu PT XYZ. Pada tahap ini, wawancara lisan dengan pihak PT XYZ dilakukan untuk mengetahui hal-hal apa saja yang dibutuhkan oleh PT XYZ dalam penyajian kinerja perusahaannya. Informasi dari PT EMS Paramitra diperoleh dan proses identifikasi user requirement juga dilakukan. Melalui proses ini, rancangan yang sesuai dengan apa yang dibutuhkan oleh pihak PT XYZ ini dibuat.

PT XYZ menginginkan Digital Dashboard dikembangkan dapat menyimulasikan dan menampilkan data-data seputar rugi-laba perusahaan dan cash cost perusahaan. Cash cost adalah biaya produksi perusahaan di lapangan yang biasanya menjadi acuan harga jual suatu produk. Tabel III berikut menampilkan kebutuhan dari PT XYZ. Pada tabel ini user requirement dipisahkan menjadi tiga bagian. Bagian umum akan menjelaskan kebutuhan user secara keseluruhan dari Digital Dashboard yang akan dibuat. Bagian rugi-laba dan cash cost akan menjelaskan kebutuhan user pada masing-masing bagian tersebut saja, seperti data apa yang perlu ditampilkan dan simulasi apa yang perlu dilakukan.

Rancangan user interface dan semua fungsionalitasnya didasarkan pada hasil identifikasi user requirement yang dilakukan pada tahap sebelumnya. Seperti yang telah disebutkan sebelumnya, rancangan keseluruhan penyajian kinerja perusahaan tidak dilakukan tetapi hanya 
perancangan pada bagian rugi-laba perusahaan saja.

TABEL III

USER REQUIREMENT PT XYZ

\begin{tabular}{|c|c|}
\hline \multirow[t]{4}{*}{ Umum } & $\begin{array}{l}\text { Bentuk tampilan data harus mudah untuk dibaca } \\
\text { dan direpresentasikan. }\end{array}$ \\
\hline & Tampilan Digital Dashboard relatif menarik. \\
\hline & $\begin{array}{l}\text { Parameter yang ditampilkan harus relevan } \\
\text { dengan kebutuhan simulasi. }\end{array}$ \\
\hline & $\begin{array}{l}\text { Pengoperasian Digital Dashboard yang relatif } \\
\text { mudah. }\end{array}$ \\
\hline \multirow[t]{2}{*}{$\begin{array}{l}\text { Rugi- } \\
\text { laba }\end{array}$} & $\begin{array}{l}\text { Tampilkan simulasi data rugi-laba setiap produk. } \\
\text { Tampilkan data rugi-laba perusahaan beberapa } \\
\text { tahun sebelumnya sebagai perbandingan. }\end{array}$ \\
\hline & $\begin{array}{l}\text { Tampilakn data rugi-laba setiap unit bisnis } \\
\text { dengan tampilan yang mudah } \\
\text { dibandingkan. }\end{array}$ \\
\hline \multirow[t]{2}{*}{$\begin{array}{l}\text { Cash } \\
\text { cost }\end{array}$} & $\begin{array}{l}\text { Tampilkan simulasi perbandingan antara cash, } \\
\text { cost, production cost dan total cost dengan sales } \\
\text { price. }\end{array}$ \\
\hline & $\begin{array}{l}\text { Pengoperasian simulasi diusahakan sama dengan } \\
\text { pengoperasian simulasi rugi-laba agar seragam } \\
\text { dan lebih mudah digunakan. }\end{array}$ \\
\hline
\end{tabular}

Rancangan Digital Dashboard yang sesuai dengan konsep Digital Dashboard itu sendiri dibuat secara sederhana dan mudah untuk dimengerti. Oleh karena itu semua komponen yang ditampilkan dalam Digital Dashboard memiliki sifat-sifat tersebut.

Digital Dashboard yang dirancang memiliki tiga halaman utama, yaitu menu utama, profit and loss, dan cash cost.

Halaman menu utama (gambar 4) adalah halaman awal yang akan user lihat pada saat pertama kali menjalankan aplikasi Digital Dashboard. Halaman ini berfungsi sebagai halaman judul yang dapat menggambarkan sekilas mengenai isi dari Digital Dashboard secara umum. Halaman menu utama ini memiliki menu navigasi halaman berupa sliding picture menu. Menu ini berfungsi untuk masuk ke halamanhalaman lainnya dari Digital Dashboard. Pada gambar 5 terlihat bahwa menu ini memiliki dua pilihan halaman yaitu halaman profit and loss yang berwarna hijau dan halaman cash cost yang berwarna oranye. User dapat memilih halaman yang ingin dikunjungi dengan menekan menu yang sesuai. Warna dan desain dari halaman ini disesuaikan dengan tema warna dari logo perusahaan PT XYZ.

Halaman profit and loss adalah halaman yang secara garis besar menyajikan prediksi mengenai masalah rugi-laba perusahaan. Halaman ini terdiri dari tiga bagian yaitu bagian navigasi, bagian hasil, dan bagian navigasi halaman.

Bagian navigasi terdapat di bagian kiri user interface dan merupakan tempat di mana user dapat mengendalikan nilai variabel-variabel yang diberikan. Komponen yang menjadi variabel disini adalah parameter-parameter yang memiliki pengaruh terhadap rugi-laba perusahaan. User dapat menggerakkan slider yang diberikan untuk mengubah nilai variabel menjadi nilai yang diinginkan. Perubahan nilai variabel ini akan memengaruhi hasil prediksi yang diberikan pada bagian hasil.

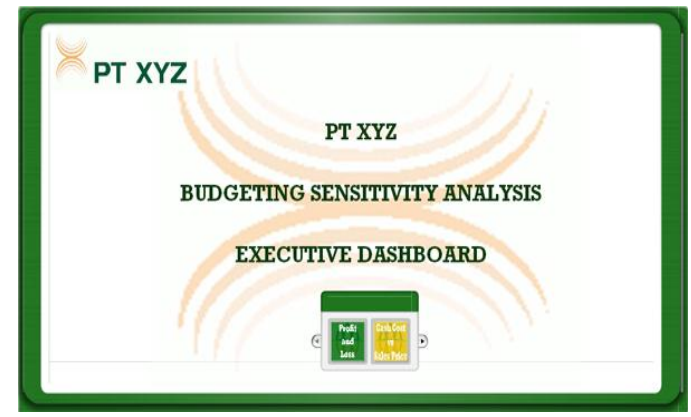

Gambar 4. Halaman menu utama

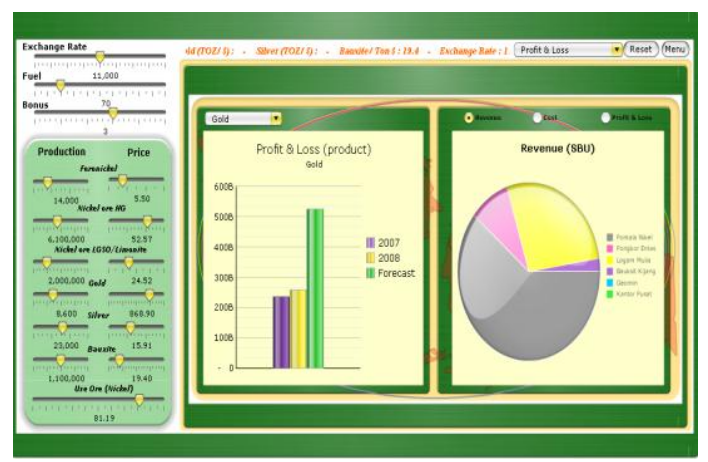

Gambar 5. Halaman profit and loss.

Bagian hasil adalah bagian yang menampilkan hasil prediksi rugi-laba perusahaan. Hasil prediksi ini didapat dari hasil perhitungan variabel-variabel yang telah ditentukan nilainya di bagian navigasi. Gambar 5 merupakan tampilan bagian hasil halaman profit and loss.

Seperti yang terlihat pada gambar 5 , bagian hasil memiliki beberapa bagian dan hasil representasi visual data ditampilkan dalam bentuk grafik. Diantaranya adalah bar chart, pie chart, dan running text.

Bar Chart atau yang biasa dikenal dengan sebutan grafik batang terdapat di sebelah kiri bagian hasil. Grafik ini berfungsi menampilkan prediksi rugi-laba perusahaan berdasarkan variabel yang telah ditentukan di bagian navigasi. Selain itu diberikan juga rugi-laba perusahaan pada tahun 2007 dan 2008 sebagai pembanding. Rugi-laba perusahaan yang ditampilkan bisa berdasarkan produk ataupun berdasarkan kesatuan perusahaan secara keseluruhan. Pada sisi kiri atas grafik batang terdapat drop down menu yang berisikan pilihan tampilan laba rugi apakah 
berdasarkan produk atau secara keseluruhan. Isi drop down menu tersebut antara lain gold, nickel, bauxite, dan corporate. Jika pilihan yang aktif adalah gold seperti pada gambar 5 maka rugi-laba yang ditampilkan hanya berdasarkan penjualan produk gold saja, tetapi jika corporate yang aktif maka rugi-laba yang ditampilkan adalah hasil penjualan keseluruhan perusahaan.

Pie Chart, grafik ini juga dikenal dengan sebutan grafik lingkaran. Grafik lingkaran ini terletak disebelah kanan bagian hasil. Grafik ini menampilkan data-data dari tiap-tiap Strategic Business Unit (SBU). PT XYZ memiliki beberapa SBU dalam usahanya, yaitu: Pomala Nikel, Pongkor Emas, Logam Mulia, Bauksit Kijang, Geomin. Kantor Pusat SBU di atas adalah menghasilkan produk yang berbeda-beda dan memberikan kontribusi yang berbeda juga untuk PT XYZ. Pilihan penampilan data-data ini dapat dilakukan dengan memilih radio button yang sesuai yang terdapat dibagian atas pie chart ini. Data-data yang dapat dilihat dari tiap-tiap SBU antara lain: Revenue, Cost, dan Profit and Loss.

Running Text, merupakan tulisan yang bergerak dari kanan ke kiri yang menampilkan jumlah variabel-variabel yang ditentukan secara detail. Tujuan dari running text hanyalah sebagai pelengkap agar tampilan tampak lebih menarik dan inovatif. Selain dari bagian navigasi dan bagian hasil, bagian navigasi halaman yang terletak di pojok kanan atas Digital Dashboard juga disediakan. Bagian ini terdiri dari drop down menu, tombol reset dan menu. Drop down menu berisikan pilihan halaman yang dapat diakses oleh user yaitu halaman profit and loss dan halaman cash cost. Tombol reset bertujuan mengembalikan nilai variabel-variabel ke nilai awal atau default sedangkan tombol menu akan mengembalikan user ke halaman utama.

Pada perusahaan tambang pada umumnya terdapat beberapa istilah biaya. Diantaranya adalah cash cost, production cost, dan total cost.

Cash Cost, biaya yang dikeluarkan pada tingkat lapangan. Artinya cash cost menyangkut biaya-biaya saat melakukan pertambangan termasuk biaya transportasi, pemurnian dan administrasi di lapangan (moneyterms, n.d.).

Production Cost, biaya ini merupakan penjumlahan dari cash cost dan biaya royalti serta pajak pertambangan (aboutpreciousmetals, n.d.).

Total Cost, biaya total atau total cost adalah penjumlahan dari production cost dan biaya depresiasi, amortisasi, dan reklamasi.

Pada dasarnya jika suatu perusahaan menjual produknya seharga cash cost yang dikeluarkan maka perusahaan itu akan rugi. Hal ini terjadi karena biaya cash cost tidak termasuk semua biaya yang dikeluarkan perusahaan untuk melakukan produksi. Oleh karena itu agar perusahaan tidak mengalami kerugian maka harga jual produk atau sales price harus lebih besar dari cash cost.

Pada halaman cash cost ini, akan ditampilkan visualisasi cash cost dan sales price pada tiga produk utama PT XYZ yaitu bauksit, nikel, dan emas. Terlihat pada gambar 6 bahwa tampilan halaman cash cost tidak terlalu berbeda dengan tampilan halaman profit and loss. Halaman ini mempunyai tiga bagian juga yaitu bagian navigasi, bagian hasil, dan bagian navigasi halaman.

Bagian navigasi dan navigasi halaman pada halaman cash cost ini sama dengan bagian pada halaman profit and loss. Yang berbeda adalah bagian hasil karena kedua halaman merepresentasikan analisis yang berbeda. Gambar 6 menunjukkan bagian hasil dari halaman cash cost ini. Terlihat pada gambar bahwa terdapat tiga jenis komponen, yaitu gauge, bar chart, dan running text.

Gauge, terdapat tiga buah Gauge atau yang biasa disebut dengan meteran pada Digital Dashboard. Masing-masing merepresentasikan data mengenai satu produk dari tiga produk yang ditampilkan. Angka pada gauge menampilkan cash cost dalam satuan USD. Bagian yang merah pada gauge menandakan batas yang tidak aman untuk perusahaan yaitu di mana cash cost sama atau lebih besar nilainya dari sales price atau harga jual produk. Seperti yang telah dibahas sebelumnya keadaan ini akan membawa kerugian kepada perusahaan.

Bar Chart, pada halaman cash cost ini juga terdapat bar chart atau grafik batang. Grafik ini merupakan representasi data yang lebih lengkap dari gauge di atasnya. Pada grafik ini ditampilkan cash cost, production cost, dan total cost dari masing-masing produk utama PT XYZ. Selain itu juga terdapat garis merah didalam bar chart ini yang menandakan sales price produk tersebut. Jika ketinggian bar chart untuk cash cost sudah sama atau lebih tinggi dari garis sales price maka sudah dapat dipastikan perusahaan akan mengalami kerugian.

Running text, komponen ini sama fungsinya dengan running text yang terdapat pada halaman profit and loss yaitu menampilkan nilai-nilai variabel dari bagian navigasi.

Tujuan dari perancangan Digital Dashboard ini adalah untuk membantu meningkatkan kinerja pengambilan keputusan bagi para eksekutif di PT XYZ. Oleh karena itu setelah proses perancangan berakhir dan Digital Dashboard selesai dibuat maka harus dilakukan pengujian terhadap Digital Dashboard tersebut. Tujuan dari pengujian ini adalah untuk mengetahui tingkat efektivitas 
Digital Dashboard dalam membantu kinerja para eksekutif PT XYZ dalam proses pengambilan keputusan. Sub bab ini akan membahas mengenai hasil dari pengujian tersebut beserta analisisnya.

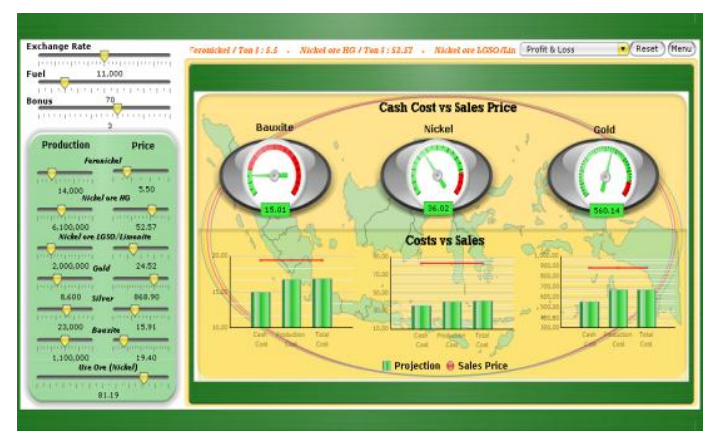

Gambar 6. Halaman Cash Cost.

Pengujian atau tahap uji coba ini akan dilakukan dengan cara memberikan form kepada pihak-pihak terkait untuk diisi. Pihak-pihak terkait inilah yang disebut penguji. Terdapat dua orang penguji di mana satu orang penguji berasal dari PT EMS Paramitra tempat dilakukannya pengembangan Digital Dashboard dan satu orang lagi berasal dari PT XYZ yaitu perusahaan yang akan menggunakan Digital Dashboard tersebut. Tujuan dari pemilihan kedua penguji ini adalah untuk mewakili pandangan dari pihak user maupun pandangan dari pihak developer. Form tersebut berisikan pernyataan-pernyataan mengenai fungsionalitas dan desain user interface dari Digital Dashboard secara keseluruhan. Penguji akan memberikan nilai tingkat kesetujuan pada pernyataan tersebut dari skala 1 sampai 5 . Nilai 1 berarti penguji sangat tidak setuju terhadap pernyataan tersebut sedangkan skala 5 berarti penguji sangat setuju dengan pernyataan tersebut.

Hasil atau nilai rata-rata pengujian Digital Dashboard dari kedua belah pihak yaitu PT EMS Paramitra selaku developer dan PT XYZ selaku user dapat dilihat pada tabel IV dibawah ini.

TABEL IV

RATa-Rata Nilai HaSil Evaluasi Digital DASHBOARD

\begin{tabular}{|c|c|c|c|}
\hline & Fungsionalitas & $\begin{array}{l}\text { Desain User } \\
\text { Interface }\end{array}$ & $\begin{array}{l}\text { Nilai Rata- } \\
\text { Rata }\end{array}$ \\
\hline $\begin{array}{ll}\text { PT } & \text { EMS } \\
\text { Paramitra }\end{array}$ & 3.85 & 3.58 & 3.71 \\
\hline PT XYZ & 4.00 & 3.91 & 3.95 \\
\hline Nilai Rata-Rata & 3.92 & 3.74 & 3.83 \\
\hline
\end{tabular}

Jika dilihat dari skala penilaian di mana angka terendah adalah angka 1 yang berarti sangat tidak setuju dan nilai tertinggi adalah angka 5 yang berarti sangat setuju maka menurut tabel di atas Digital Dashboard yang dikembangkan mendapat nilai 3.83. Hal ini berarti secara keseluruhan penguji setuju dengan pernyataan- pernyataan yang terdapat dalam form pengujian. juga dapat dilihat bahwa tingkat fungsionalitas dari Digital Dashboard mendapat nilai cukup tinggi dan menandakan bahwa Digital Dashboard berfungsi dengan baik dan sesuai dengan kebutuhan perusahaan. Demikian juga dari segi desain user interface yang walaupun mendapat nilai lebih rendah dari tingkat fungsionalitas tetapi masih dalam skala setuju.

Hal lain yang dapat dilihat adalah rata-rata penilaian yang diberikan kedua penguji juga dapat dikatakan relatif sama atau tidak terlalu berbeda secara signifikan. Perlu diperhatikan bahwa kedua penguji masing-masing mewakili suatu kedudukan yaitu sebagai developer dan user. Kesamaan nilai yang diberikan dapat menunjukkan bahwa adanya kesatuan pendapat dan pengertian mengenai requirement apa saja yang harus ada dan diperlukan dalam suatu Digital Dashboard. Hal ini hanya bisa didapat jika ada komunikasi yang baik antara pihak developer dengan pihak user sehingga setiap kebutuhan user dapat dipenuhi dengan baik oleh developer.

Data hasil pengujian di atas membawa peneliti pada suatu kesimpulan di mana Digital Dashboard yang dikembangkan dapat membantu perusahaan dalam proses pengambilan keputusan. Selain itu rancangan desain user interface Digital Dashboard juga sudah berhasil memenuhi prinsip-prinsip dari Human Computer Interaction sehingga cukup mendukung interaksi antara user dengan aplikasi komputer.

\section{Kesimpulan}

Kesimpulan. Beberapa parameter utama berpengaruh besar pada kinerja keuangan rugilaba PT XYZ. Pertama, nilai tukar Rupiah terhadap Dollar Amerika (USD). PT XYZ yang memiliki penghasilan dalam Dollar Amerika dan akan memperoleh keuntungan yang lebih besar jika nilai tukar Dollar Amerika terhadap Rupiah dalam keadaan tinggi. Kedua, harga Bahan Bakar Minyak (BBM). Dalam proses produksi PT XYZ menggunakan Bahan Bakar Minyak (BBM). Oleh karena hal inilah harga BBM berpengaruh kuat pada rugi-laba PT XYZ.

Ketiga, bonus yang diberikan kepada karyawan. PT XYZ memberikan bonus kepada karyawannya dengan jumlah beberapa kali dari gaji pokok mereka. Pemberian bonus berpengaruh signifikan mengingat jumlah dari karyawan PT XYZ yang tergolong banyak. Keempat, perbandingan jumlah nikel dengan bijih besi pada feronikel yang diproduksi. Semakin banyak komposisi besi yang ada pada feronikel maka semakin sedikit biaya produksi yang harus dikeluarkan oleh PT XYZ. Nikel dan feronikel 
adalah produk utama yang diproduksi PT XYZ sehingga menjadikan hal ini berpengaruh besar terhadap rugi-laba perusahaan secara keseluruhan. Kelima, jumlah produksi yang terjual dan harga jual produk. Hal ini sebenarnya merupakan hal yang umum dalam menentukan rugi-laba perusahaan di mana semakin banyak produk yang terjual dengan harga tinggi akan semakin meningkatkan laba perusahaan.

Digital Dashboard adalah suatu tools yang dapat digunakan untuk merepresentasikan data secara visual dan interaktif. Suatu Digital Dashboard yang baik harus dapat menampilkan data dengan tampilan yang efisien, menarik dan padat informasi dengan tetap memerhatikan fungsionalitas dari Digital Dashboard itu sendiri.

Penggunaan Digital Dashboard dalam menyajikan sensitivity analysis kinerja keuangan dapat membantu eksekutif perusahaan dalam melakukan pengambilan keputusan. Hal ini harus didukung dengan rancangan dari Digital Dashboard yang sesuai dengan kebutuhan dari eksekutif perusahaan tersebut.

Saran. Hasil penelitian ini menyarankan bagi perusahaan lainnya untuk memertimbangkan penggunaan Digital Dashboard untuk menggantikan tampilan data sensitivity analysis kinerja keuangan perusahaan mereka yang masih konservatif. Hal ini didasarkan karena kemampuan Digital Dashboard untuk menampilkan data dengan tampilan yang lebih mudah dimengerti sehingga proses pengambilan keputusan bisa lebih efisien dan efektif.

Dalam melakukan perancangan desain user interface suatu Digital Dashboard jangan hanya memperhatikan dari sisi keringkasan dan daya tarik Digital Dashboard tersebut tetapi juga harus memperhatikan sisi fungsionalitas dan yang terpenting adalah kebutuhan dari user Digital Dashboard yang peneliti kembangkan.

\section{Referensi}

[1] Akib, Faisal, Sistem Informasi Eksekutif, Teknik Informatika, http://teknik-informatika.com/sisteminformasi-eksekutif/, February 11, 2010.

[2] W. Beushcel, In: Encyclopedia of Decision Making and Decision Support Technologies, Dashboard for Management, vol. 1, pp. 116123, 2006.
[3] L. Breierova \& M. Choudhari, An Introduction to Sensitivity Analysis, Massachusetts Institute of Technology, Massachusetts, pp. 41-107, 2001.

[4] G. Pietersz, Cash Cost in Mining, Moneyterms, http://moneyterms.co.uk/cash_cost_mining/, 2005, retrieved February 11, 2010.

[5] A.J. Dix, J.E. Finlay, G.D. Abowd, \& R. Beale, Human-Computer Interaction, 3rd ed., Prentice Hall, USA, 2003.

[6] A. Gorry \& M.S. Scott-Morton, In: Sloan Management Review, A Framework for Information Systems, vol. 13(1), pp. 56-79, 1971.

[7] D. Indayanti, Sistem Pendukung Keputusan, Gunadarma e-learning, http://deasy.staff.gunadarma.ac.id/Download s/files/8446/SPK.doc, pp. 1-7, retrieved February 11, 2010.

[8] R.I. Mann \& H.T. Watson, "A Contingency Model For User Involvement in DSS Development," MIS Quarterly, vol. 8(1), pp. 27-38, 1984.

[9] Production Cost. (n.d.), http://www.aboutpreciousmetals.com/Minin g/Glossary/production_costs.htm, retrieved February 11, 2010.

[10] PT Aneka Tambang, ANTAM Described, http://www.antam.com/index.php?option=co m_content\&task=view\&id=32\&Itemid=2, retrieved February 11, 2010.

[11] E. Richardo, "Perancangan Digital Dashboard System Untuk Menyajikan Key Performance Indicators: Studi Kasus Bidang Riset dan Penelitian Fakultas Ilmu Komputer Universitas Indonesia,” B.S Thesis, Fakultas Ilmu Komputer, Universitas Indonesia, Indonesia, 2008.

[12] B. Shneiderman, Designing the User Interface: Strategies for Effective HumanComputer Interaction, 2nd ed., Addison Wesley, USA, 1992.

[13] H.A. Simon, Administrative Behaviour, 4th ed., The Free Press, New York, 1997.

[14] E. Turban, R. Sharda, \& D. Delen, Decision Support and Business Intelligence Systems, PrenticeHall, USA, 2007. 